\title{
Study on a Path of Precision Poverty Alleviation in Poor Rural District in China: A Case Study of the Chixi Village in Fuding, Fujian, China*
}

\author{
Guangying Zhang \\ Ningde Normal University, Fujian, China
}

\begin{abstract}
Now, precise poverty alleviation is an important policy for rural work in China. Rural tourism poverty alleviation is an important way to get rid of poverty in rural areas of China, which is also a means of precision poverty alleviation in Chinese poor rural districts. Chixi village is noted as "the first China poverty village" in China. In recent years, Chixi village has been integrating tourism development and poverty alleviation. The study found that tourism development is playing an important role in the process of poverty alleviation and well directly benefits people in Chixi. This successful experience is worth learning and studying in depth.
\end{abstract}

Keywords: tourism development, precision poverty alleviation, Chixi village, China

\section{Introduction}

Poverty phenomenon is accompanied by the development of human history and has become a chronic disease which restricts and besets the human survival and development. Poverty is considered as the impoverishment and embarrassment in economy and spirit, which is a meager comprehensive phenomenon in both the material life and the spiritual life (Baidu Encyclopedia, n.d.).

In 2016, Xu Shaowei, the director of China National Development and Reform Commission, said that there are 70,170,000 poor people living in Chinese rural areas, of which 835,000 villages are very poor. China not only has a total of 14 contiguous poor areas but also has a considerable number of people living below the poverty line (China News, 2016). Therefore, Chinese government must face serious poverty alleviation problems, especially in vast China rural areas. According to the Chinese Notice of action plan for rural tourism poverty alleviation project and plan for action project, by 2016, 22,651 poor villages as key rural villages will be established to develop tourism and reduce poverty. Up to 7,477,000 poor people will be associated with this project.

In "The 13th Five-Year Plan of China", the goal of China National Tourism Administration is to help 10,000 key rural villages to get income of 1 million Yuan one year per village through developing tourism, and to try their best to help poor people to get 10,000 Yuan $(\$ 1,470)$ one year through implementing rural tourism poverty alleviation project (National Administration of People's Republic of China, 2016). This is a grand national project for China and Chinese poor people. At present, we must see many Chinese tourism researchers are actively and deeply involved in this project.

\footnotetext{
* This study is supported by social science planning of Fujian Province (No. FJ2015B192) and the new century talent project of Fujian Province (No. [2015]54).

Guangying Zhang, Professor, The Department of Tourism, Ningde Normal University. Email: 584912281@qq.com.
} 


\section{Literature Review}

Studies focusing on the impact of tourism poverty alleviation on the regional economy began in the 1970s of the last century. Frechtling (1974) made an exploratory study on the regional influence of tourism industry. It was the first national report on estimated tourism expenditure in the United States. On the basis of the research of Frechtling (1974), Wassenaar (1981) put forward a model to analyze the regional influence of tourism and gave a set of step-by-step procedures and guidelines for determining the size, nature, and economic impact of a community's visitor trade. Since then, in this research field, a large number of papers have been appearing. Among them, the most representative opinion is "Pro-poor Tourism" theory, which was proposed by the British Development Council (conducive to the development of poor people's tourism, referred to as PPT, 1999) (Ashley, Roe, \& Goodwin, 2001). PPT study shows that although tourism caused a lot of problems in the global development, it is still considered having great potential in the development of economy and eliminating poverty, and if the direction of tourism's development and strategies had been effective adjustment, tourism industry would play a more important role in the development of anti-poverty and create more opportunities for poverty alleviation. But from December 2009, when the World Climate Change Conference was held in Copenhagen, the research of tourism poverty alleviation was turned to focus on studying the climate change and the development of ecologically fragile poverty areas. The research results mainly appeared in the form of news reports rather than papers. Kennedy and Dornan (2009) studied the NGO organizational form, support mode, and role of in the process of tourism poverty alleviation. Kiernan (2013) focused on the nature conservation, geo-tourism, and poverty reduction nexus in developing countries. Zhang (2012) believed that the poverty alleviation tourism could contribute to the communication between poor areas and out world, industrial and urban-rural areas, and can promote the all-round development of the poor areas in material economy, including system, spirit, psychology, environment, and other aspects. Deng, Zeng, and Luo's (2015) study is based on the background of China's accurate poverty alleviation. His team analyzed the two aspects of tourism poverty alleviation about target population identification and tourism poverty alleviation project identification, proposed the market identification mechanism and the "will-ability" identification model, and constructed the "RHB" framework for identifying poverty alleviation projects. Wang and Guo (2015) believed that the policies and measures of poverty alleviation would benefit the real poverty and population in future. They believed that government could fundamentally eliminate the factors and obstacles of the poverty and sustainable poverty reduction goals would be achieved. Chen and Ji's (2016) paper showed that rural tourism precise poverty is a dynamic, continuous feedback, organic open system, which must depend on accurate identification, precise poverty assistance, poverty alleviation precise management.

\section{Methodology}

\section{Research Method}

This paper tries to solve some of the problems about where the poor rural villages are in the famous scenic spot in developing countries, how to get rid of poverty through tourism poverty alleviation, how to improve the people's livelihood, and how to help the people to have spiritual satisfaction.

In this paper, the author develops the argument based on a review and interpretation of the literature, field research, and data survey. Through field investigation, the author collected the primary material and data for this study and also interviewed local government, residents, tourism companies, etc.. 
The author investigated the tourism resources about the Chixi village, classified the tourism resources, visited local travel companies, interviewed residents to get the data about the residents' income from tourism enterprises, read and analyzed related materials to get Chixi village's total economic development data, in particular concerning the Chixi village tourism development data in recent 10 years.

In the first stage, in order to know the tourism development relationship between Chixi village and Taimu Mountain scenic area, Chixi village's location conditions were analyzed. Analysis results are found, showing that as a poor village located in Taimu Mountain scenic area, Chixi village has location advantage to implement tourism poverty alleviation.

For the second stage, according to People's Republic of China National Standard About Classification, Investigation and Evaluation of Tourism Resources (GB/T 18972-2003), Chixi village tourism resources were analyzed, classified, and evaluated, and the consequence shows that Chixi village has a distinctive tourist resource, and Chixi village's tourism alleviation development benefits from its distinctive tourist resource.

For the third stage, the past 11 years data of Chixi village's economic development were analyzed. At the same time, there are many materials about Chixi village development, including the number of tourism companies, the data of the residents' income from tourism development. Based on all of these materials, the results of Chixi village's tourism development in poverty alleviation were displayed.

In the final stage, based on the front of location analysis, resource analysis, and numerical analysis, the research results indicate that Chixi village is a typical poor village in tourism poverty alleviation, and that Chixi village residents choose the mode of tourism poverty alleviation to raise their income and get rid of poverty. The success of tourism poverty alleviation experience and methods about Chixi village are worth learning, using for reference and promoting.

\section{Location Condition Analysis}

Location condition of Chixi village. Chixi village is made up of 14 small natural villages, belonging to Panxi Town, located in Fuding City, southwest of Fujian Province. Chixi village is $120 \mathrm{~km}$ apart from Wenzhou city, $200 \mathrm{~km}$ apart from Fuzhou city, and only $50 \mathrm{~km}$ apart from Mindong airport. Especially, Chixi village is located in the west of 5A National Scenic Area of Taimu Mountain. Taimu Mountain is also the World Geological Park.

Resources condition of Chixi village. Chixi village main resources include mountains, rivers, cropland, and other ecological resources, such as tea, forest, bamboo, fish, and so on. Chixi village has been surrounded by mountains, layer upon layer of peaks and knolls. Jiuli stream and Xiashan stream are joined here and flowed into the East China Sea. Around Chixi village, there are Castle Peak Pinnacle, rugged rock formations, and amazing caves. Chixi village is composed of rushing rivers, luxuriant forests, and precipitous topography. All of these are endowed with fascinating eco-landscape and constitute Jiuli stream waterfall scenic spot. Jiuli stream waterfall scenic spot is around 25 square kilometers, which is an important scenic spot for the Taimu Mountain scenic area.

Chixi village has $90 \%$ forest vegetation coverage rate, but less arable land, so this typical characteristic is called "eight mountains one water and one field". Some small amounts of arable lands are concentrated in the eastern basin area in the center of the village and are used to grow rice and vegetables. Part of the arable lands are hillside and are used to grow tea.

Population conditions of Chixi village. As of 2015, Chixi village has 408 households, a total of 1,808 people, among which, the She nationality population are 802 , accounting for $40 \%$ of the total population. 


\section{Tourism Resource Condition of Chixi Village}

According to the available information and the author's investigation, Chixi village tourism resources can be classified into 8 main categories, 18 sub-categories, 35 basic types, and 67 resource monomers (see Table 1).

Table 1 shows: First, there are many types and class diversity of tourism resources in Chixi village. The Chixi village tourism resources belong to 8 main classes, 18 subtypes and 35 basic types, and 67 resource monomers. Among these can be divided 3 first grade tourism resources, 33 second grade tourism resources, 30 third grade tourism resources and 1 fourth grade tourism resource. Second, although Chixi village belongs to Taimu Mountain scenic area, Taimu Mountain scenic area is noted for mountain geological landscape resources, Chixi village highlights its cultural tourism resources. Among the 67 monomers of tourism resources, 42 are cultural tourism resources, accounting for $63.6 \%$ of the total resource monomers. Third, She nationality tourism resources are unique resources for Chixi village. Fourth, as the first village of poverty alleviation in China, in the past 30 years process of poverty alleviation, a large number of personnel records, historical poverty alleviation records have been kept. At Chixi village, the formation of the humanities tourism resources of poverty alleviation is unique.

Table 1

Classification and Evaluation of Chixi Village Tourism Resources

\begin{tabular}{|c|c|c|c|c|}
\hline Main class & Subtype & Fundamental type & Specific resources & Grade \\
\hline \multirow{8}{*}{ A: Land scenery } & \multirow{7}{*}{$\begin{array}{l}\text { AA: Comprehensive } \\
\text { natural tourist destination }\end{array}$} & \multirow{4}{*}{$\begin{array}{l}\text { AAA: Hilly tourist } \\
\text { destination }\end{array}$} & Dongsan Hillock & Second grade \\
\hline & & & Shi Rock & Second grade \\
\hline & & & Ban Shan & Second grade \\
\hline & & & Fox Hillock & Second grade \\
\hline & & \multirow{3}{*}{$\begin{array}{l}\text { AAB: Valley tourism } \\
\text { destination }\end{array}$} & Brook Valley & Second grade \\
\hline & & & Jiuli River Valley & Second grade \\
\hline & & & Xiashan River Valley & Third grade \\
\hline & $\begin{array}{l}\text { AC: Geological and } \\
\text { geomorphological process } \\
\text { features }\end{array}$ & ACF: Cliff rock seam & Fox Hillock Rock Seam & Second grade \\
\hline \multirow{7}{*}{ B: Waters scenery } & \multirow[b]{2}{*}{ BA: Stream segment } & \multirow{2}{*}{$\begin{array}{l}\text { BAA: Sightseeing and } \\
\text { recreation stream } \\
\text { segment }\end{array}$} & Jiuli River Stream Segment & Second grade \\
\hline & & & $\begin{array}{l}\text { Three Rivers Flow Together } \\
\text { Stream Segment }\end{array}$ & Third grade \\
\hline & \multirow{3}{*}{$\begin{array}{l}\text { BB: Natural lakes and } \\
\text { marshes }\end{array}$} & \multirow{3}{*}{ BBC: Pool } & Biyu Pool & Third grade \\
\hline & & & Turtle Pool & Third grade \\
\hline & & & Huli River Pool & Third grade \\
\hline & \multirow{2}{*}{ BC: Waterfall } & BCA: Water fall & Xiashanxi Water Fall & Third grade \\
\hline & & BCB: Hydraulic drop & Xiashanxi Hydraulic Drop & Second grade \\
\hline \multirow{6}{*}{ C: Biological landscape } & \multirow{4}{*}{ CA: Trees } & CAA: Forestry & $\begin{array}{l}\text { Xiashanxi Waterfront } \\
\text { Forestry }\end{array}$ & Second grade \\
\hline & & \multirow{2}{*}{ CAB: Bused tree } & Xidong Bused Tree & First grade \\
\hline & & & Stream Banks Maple Tree & Second grade \\
\hline & & CAC: Special Tree & Waicuo Old Trees & Second grade \\
\hline & \multirow{2}{*}{ CD: Wildlife habitat } & \multirow{2}{*}{$\begin{array}{l}\text { CDA: Aquatic animal } \\
\text { habitat }\end{array}$} & Craspedacusta & Fourth grade \\
\hline & & & Wild Fish & Second grade \\
\hline
\end{tabular}


(Table 1 continued)

\begin{tabular}{|c|c|c|c|c|}
\hline Main class & Subtype & Fundamental type & Specific resources & Grade \\
\hline \multirow{2}{*}{$\begin{array}{l}\text { D: Weather and climate } \\
\text { landscape }\end{array}$} & DA: Light phenomenon & $\begin{array}{l}\text { DAA: Place for } \\
\text { observing the sun, the } \\
\text { moon, and the stars }\end{array}$ & $\begin{array}{l}\text { Fox Hillock Observation } \\
\text { Deck }\end{array}$ & Second grade \\
\hline & $\begin{array}{l}\text { DB: Weather and climate } \\
\text { phenomena }\end{array}$ & DBA: Fog and mist & Sea of Clouds & Second grade \\
\hline \multirow{3}{*}{$\begin{array}{l}\text { E: Site and historical } \\
\text { remains }\end{array}$} & \multirow{3}{*}{$\begin{array}{l}\text { EB: Social economic and } \\
\text { cultural activities relics }\end{array}$} & $\begin{array}{l}\text { EBA: Historical event } \\
\text { occurrence place }\end{array}$ & \begin{tabular}{|l} 
Site of the People's \\
Assembly Hall
\end{tabular} & Second grade \\
\hline & & $\begin{array}{l}\text { EBB: Military relics and } \\
\text { ancient battlefield }\end{array}$ & The Kenglinong castle walls & Third grade \\
\hline & & EBE: Traffic relics & Ancient road & Third grade \\
\hline \multirow{22}{*}{$\begin{array}{l}\text { F: Buildings and } \\
\text { facilities }\end{array}$} & \multirow{14}{*}{$\begin{array}{l}\text { FA: Comprehensive } \\
\text { cultural tourism } \\
\text { destination }\end{array}$} & \multirow{5}{*}{$\begin{array}{l}\text { FAB: Recreation and } \\
\text { leisure resort }\end{array}$} & Yuxiang Park & First grade \\
\hline & & & $\begin{array}{l}\text { She Nationality Rural } \\
\text { Leisure Park }\end{array}$ & Second grade \\
\hline & & & Genle park & Third grade \\
\hline & & & CS field base & Third grade \\
\hline & & & Huli Big White Tea & Third grade \\
\hline & & \multirow{3}{*}{$\begin{array}{l}\text { FAC: The place for } \\
\text { religion and sacrifice }\end{array}$} & Du Family ancestral halls & First grade \\
\hline & & & Xiaoxi ancestral halls & Second grade \\
\hline & & & Chu family ancestral halls & Second grade \\
\hline & & $\begin{array}{l}\text { FAD: Garden recreation } \\
\text { area }\end{array}$ & The She nationality stockade & Second grade \\
\hline & & \multirow{5}{*}{$\begin{array}{l}\text { FAH: Animals and } \\
\text { plants exhibition place }\end{array}$} & Jiupinxiang lotus pond & Third grade \\
\hline & & & Butterfly ecology garden & Third grade \\
\hline & & & Paradise fish of China & Third grade \\
\hline & & & Tea plantation & Second grade \\
\hline & & & Rape garden & Second grade \\
\hline & $\begin{array}{l}\text { FC: Landscape } \\
\text { architecture and secondary } \\
\text { attribute building }\end{array}$ & $\begin{array}{l}\text { FCH: Upright stone } \\
\text { tablet }\end{array}$ & $\begin{array}{l}\text { Monument for first village } \\
\text { poverty alleviation in China }\end{array}$ & Third grade \\
\hline & \multirow{4}{*}{$\begin{array}{l}\text { FD: Residence and } \\
\text { community }\end{array}$} & \multirow{4}{*}{$\begin{array}{l}\text { FDA: Tradition and } \\
\text { vernacular architecture }\end{array}$} & $\begin{array}{l}\text { The ancient house group of } \\
\text { Family Du }\end{array}$ & Second grade \\
\hline & & & \begin{tabular}{|l|} 
Xinan ancient village \\
\end{tabular} & Third grade \\
\hline & & & Xiaoxi ancient village & Third grade \\
\hline & & & Dongpingli ancient village & Third grade \\
\hline & FF: Transport facilities & FFE: Path along the cliff & Xiaganwei anchor steps & Second grade \\
\hline & \multirow{2}{*}{$\begin{array}{l}\text { FG: Hydraulic engineering } \\
\text { construction }\end{array}$} & $\begin{array}{l}\text { FGC: Canals and } \\
\text { channels passage }\end{array}$ & Chixidian canal & Second grade \\
\hline & & FGB: Old well & Dujiabao old well & Second grade \\
\hline \multirow{9}{*}{ G: Tourist commodities } & \multirow{9}{*}{$\begin{array}{l}\text { GA: Local tourist } \\
\text { commodities }\end{array}$} & \multirow{5}{*}{ GAA: Food diet } & Meat of pig head & Third grade \\
\hline & & & Black rice & Third grade \\
\hline & & & Zongzi & Third grade \\
\hline & & & She national rice wine & Third grade \\
\hline & & & Pickled vegetables & Second grade \\
\hline & & \multirow{2}{*}{$\begin{array}{l}\text { GAB: Products of } \\
\text { agriculture and forestry }\end{array}$} & Dried bamboo shoots & Second grade \\
\hline & & & Dry fish & Second grade \\
\hline & & $\begin{array}{l}\text { GAD: Chinese herbal } \\
\text { medicines and products }\end{array}$ & She medicine & Third grade \\
\hline & & $\begin{array}{l}\text { GAE: Traditional } \\
\text { hand-made products and } \\
\text { crafts }\end{array}$ & Bamboo weaving & Second grade \\
\hline
\end{tabular}


(Table 1 continued)

\begin{tabular}{|c|c|c|c|c|}
\hline Main class & Subtype & Fundamental type & Specific resources & Grade \\
\hline \multirow{10}{*}{ H: Humane activities } & \multirow{2}{*}{$\begin{array}{l}\text { HA: Important people and } \\
\text { event record }\end{array}$} & \multirow{2}{*}{ HAB: Event } & $\begin{array}{l}\text { Historical event about first } \\
\text { village poverty alleviation }\end{array}$ & Second grade \\
\hline & & & $\begin{array}{l}\text { Cultural relics related } \\
\text { poverty }\end{array}$ & Second grade \\
\hline & \multirow{8}{*}{ HC: Folk custom } & \multirow{3}{*}{$\begin{array}{l}\text { HCA: Local custom and } \\
\text { folk etiquette }\end{array}$} & Toast song & Third grade \\
\hline & & & Wedding song & Third grade \\
\hline & & & She nationality marriage & Third grade \\
\hline & & \multirow{2}{*}{ HCB: Folk festival } & San Yue San & Third grade \\
\hline & & & Si Yue Ba & Third grade \\
\hline & & $\begin{array}{l}\text { HCC: Folk performing } \\
\text { arts }\end{array}$ & The folk song & Third grade \\
\hline & & $\begin{array}{l}\text { HCD: Folk fitness } \\
\text { activities and events }\end{array}$ & Bamboo dance & Second grade \\
\hline & & $\begin{array}{l}\text { HCH: Characteristic } \\
\text { costume }\end{array}$ & She costume & Third grade \\
\hline
\end{tabular}

Note. Sources of information: (1) author field research; (2) The Government of Panxi Town, Fuding City, A Village Features Special Planning for Chixi Village She Nationality, Panxi Town, Fuding City (2013-2033); and (3) Tourism Bureau of Fujian Province, The Chixi Village Tourism poverty alleviation program (2015-2035).

\section{The Tourism Development Relationship Between Taimu Mountain and Chixi Village}

About Taimu Mountain. Taimu Mountain is a famous 5A grade scenic area in China. It is located in the city of Fuding, Fujian, China. Taimu Mountain scenic area covers a total area of 92.02 square kilometers, consisting of Taimu Mountain scenic spot, Fu Yao Islands scenic spot, Jiuli stream and waterfall scenic spot, Qingchuan seashore scenic spot, and Sanyuan Cuihu scenic spot. The Chixi village is located in Jiuli stream and waterfall scenic spot.

Analysis of the development of Taimu Mountain tourism. In order to analyze the development of Taimu Mountain tourism, the number of visitors to Taimu Mountain from 2004 to 2014 was collected and analyzed (see Table 2).

Especially, the number of Jiuli stream scenic spots was concerned.

Table 2

The Number of Visitors of Taimu Mountain from 2004 to 2014

\begin{tabular}{|c|c|c|c|c|c|c|}
\hline Years & $\begin{array}{l}\text { Taimu Mountain } \\
\text { scenic spot }\end{array}$ & $\begin{array}{l}\text { Fu Yao Island } \\
\text { scenic spot }\end{array}$ & $\begin{array}{l}\text { Jiuli stream and } \\
\text { waterfall scenic } \\
\text { spot }\end{array}$ & $\begin{array}{l}\text { Qingchuan } \\
\text { seashore scenic } \\
\text { spot }\end{array}$ & $\begin{array}{l}\text { Sanyuan Cuihu } \\
\text { scenic spot }\end{array}$ & Total \\
\hline 2004 & 341,208 & 13,000 & 5,000 & 2,300 & 1,050 & 362,558 \\
\hline 2005 & 292,947 & 40,000 & 5,000 & 2,750 & 1,200 & 341,897 \\
\hline 2006 & 331,936 & 40,000 & 5,032 & 3,000 & 1,120 & 381,088 \\
\hline 2007 & 324,453 & 37,896 & 12,125 & 3,200 & 1,250 & 378,924 \\
\hline 2008 & 281,823 & 21,506 & 10,754 & 3,300 & 1,400 & 318,783 \\
\hline 2009 & 347,415 & 18,109 & 92,158 & 3,350 & 1,700 & 462,732 \\
\hline 2010 & 372,101 & 22,607 & 83,584 & 3,500 & 2,000 & 483,792 \\
\hline 2011 & 451,739 & 28,451 & 91,446 & 3,550 & 2,150 & 577,336 \\
\hline 2012 & 524,732 & 47,465 & 89,635 & 3,630 & 2,180 & 667,642 \\
\hline 2013 & 554,623 & 48,214 & 91,563 & 3,650 & 2,200 & 700,250 \\
\hline 2014 & 596,513 & 56,541 & 92,648 & 3,720 & 2,250 & 751,672 \\
\hline
\end{tabular}

Note. Data source: (1) author household survey, with special thanks to Mr. Du Bingzhuo; (2) Taimu Mountain Tourism Bureau Master Plan for Taimu Mountain National Scenic Area (2015-2030). 
Table 2 shows that, over the past 11 years, the number of visitors to Taimu Mountain has been increasing. Especially, Chixi village of Jiuli stream and waterfall scenic spot tourists increased significantly, and the number of visitors increased from 5,000 in 2004 to about 92,648 in 2014, an increase of 463 times. Then, the article will analyze the development of Jiuli stream and waterfall scenic spot and the benefits of tourist growth for the Chixi village tourism development.

\section{The Tourism Development Process of Chixi Village from 2004 to 2016}

The actions are taken for Chixi village tourism poverty alleviation. In order to find more relevant information about Chixi village tourism poverty alleviation, field investigation method and interview investigation method were used. We conducted a survey of the Chixi village committee to obtain the historical data of poverty alleviation about this village. We talked with some villagers about their views on poverty alleviation and the family income data of the villagers. We surveyed five travel companies to acquire the methods and measures for tourism companies to develop Chixi village tourism poverty alleviation. We found that actions had been taken to develop Chixi village tourism for poverty alleviation and Chixi villagers benefited from the development of tourism poverty alleviation.

First, tourism companies ware permitted to enter Chixi village to develop local tourism. Wanbohua Tourism Company is the first company allowed to enter the village. From 2004 to 2014, Wanbohua has invested more than 7 million Yuan improving Chixi village tourism facility. This company has developed Jiuli river rafting, Jiuli creek road, Jiuli stream exploration tourism project.

As of 2016, there are five tourism companies which were allowed to enter Chixi village, including Wanbohua, Dingyi, Genle Yuan, Dujia Leisure Farm, and Chiwenfeng. Under the investment of these tourism companies, a lot of tourism projects were developed, such as bamboo rafting, real CS field base, eco agricultural sightseeing garden, colorful butterfly garden, Genle park, and so on. In addition, small supermarkets, farmhouse and specialty stores have also emerged in the village. Over 160 residents are working in these companies and tourism enterprises.

Second, the local government raised large sums for highway construction.

In 1993, the highway from Chixi village to Panxi town was constructed. This road is not smooth, dirty, and has no cement, but it is the only way to get to the town. The construction of such highway created a chance for Chixi village to be known by the outside world.

In 2015, 20.5 kilometer road which was invested around the 399 million Yuan, runs from Shenhai expressway was built by the local government. This is a smooth, strongly built highway, and is very convenient for tourists to enter Chixi village. At the same time, the local government also helped to upgrade the highway from Chixi village to panxi town. All of these mostly improve the traffic conditions for Chixi village, which is convenient for travelers. Chixi village becomes an important fulcrum in the west Taimu Mountain, and causes Chixi village and the coastal scenic spots in Fujian province to merge. All of that, Chixi village has more opportunities to enter the whole tourism market of Fujian province and Zhejiang province.

Third, the model of tourism development for Chixi village precision poverty alleviation was created by Chixi village residents, which was called "company + cooperative organization + land + farmers" model. In this model, farmers integrate their private land together to form cooperatives to guide farmers to grow agriculture products in line with the needs of tourists, and tourism companies are responsible for marketing, ensuring these agricultural products to be sold to tourists with the best price. This mode improves local 
agriculture production enthusiasm. Farms have more smooth way to sell their agricultural products and service for tourist. Tea, fruit, vegetables, fish, poultry, and other local agriculture products are directly consumed by tourists. These actions raise farmers' income and are good for farmers to get rid of poverty.

Fourth, active actions are taken to protect the ecological environment.

In 2003, a small-size hydropower project was going to be built by a company at Xiashan stream. This caused a strong opposition from the Chixi villagers. Finally, this project was aborted.

In order to improve the village's ecological environment, village's pacts are taken by Chixi residents. For example, the forest is forbidden to be cut down, and fishing wild fish from stream is also not allowed, vegetables and flowers are required to be planted around the house field. In the process of rural construction, all residents are required to highlight the local flavor and local characteristics, to protect historical buildings. All these measures are taken to protect the ecological environment. Benefited from the improvement of ecological environment, more and more tourists are attracted to Chixi village.

Fifth, the farmers' per capita net income increased.

According to the data of per capita net income of farmers in Chixi village in 2010, 2011, 2012, 2013, 2014, and 2015 (see Table 3), it is found that the per capita net income of farmers in Chixi village is increasing year by year. By 2015, the per capita net income is 3.36 times of per capita net income in 2004. It can also be found that the growth of per capita net income of Chixi farmers is positively related to the tourism development in Chixi village.

Table 3

Farmers' Per Capita Net Income in 2010-2015

\begin{tabular}{lc}
\hline Year & Per capita net income (Yuan) \\
\hline 2010 & 4,068 \\
2011 & 5,353 \\
2012 & 7,350 \\
2013 & 9,430 \\
2014 & 11,674 \\
2015 & 13,689 \\
\hline
\end{tabular}

Note. Data source: (1) provided by Chixi villagers committees; and (2) Tourism Bureau of Fujian Province, The Chixi Village Tourism poverty alleviation program (2015-2035).

Chixi residents' tourism revenue. Through the research, in normal times, there are around 160 people working in tourism companies. During the tourist season, there are up to more than 400 people in tourism companies. The wages of the villagers working in the tourism company range from 130 to 150 Yuan per person per day, and annual salary per person is more than 30,000 Yuan. These statistics only include those who are directly engaged in tourism. The amount of revenue would be considerable if the indirect income from tourism is considered. In Chixi village, the total number of households is 408, and nearly 150 households have received an income of more than 100,000 Yuan a year, which account for 37\% of the total household number.

Analysis of residents' income from tourism. Table 2 shows that in the past 11 years, from 2004 to 2014, farmers' per capita net income increased more than 4 times.

Seen from the contrastive analysis of Tables 2 and 3, the growth of farmers' per capita net income is proportionate to the increased volume of tourists of Jiuli stream and waterfall scenic spot. 
The overall data reflect that the development of the tourism industry and the growth of the number of tourists are the direct factors causing the increase of the villagers' income, and they also objectively promote the practice of tourism poverty alleviation.

\section{Results and Discussion}

First, in the developing countries, if an impoverished village has better location, it will have more development opportunities for poverty alleviation than others. As Chixi village is located in a famous scenic area, which has got much benefit from Taimu Mountain tourism development. This paper shows that the tourism development of Taimu Mountain scenic area directly promotes Chixi village tourism poverty alleviation development and increases the income of the villagers.

Second, tourism alleviates the poverty in the impoverished villages. It is important that the impoverished villages have characteristics resources for implementing tourism poverty alleviation. Although the Chixi village can rely on Taimu Mountain to develop tourism, it has unique advantages and natural tourism resources and cultural tourism resources are important. Especially, Chixi village She nationality culture resource and poverty alleviation procession records are unique. All of these are benefits for tourism poverty alleviation.

Third, the local government plays an important role in the process of poverty alleviation in impoverished villages. Depending on the local government investment, Chixi village improves the highway conditions and other basic conditions. Tourists have more convenient traffic to get to Chixi village.

Fourth, as a impoverished village, Chixi village deeply integrated its tourism development into poverty alleviation, and made tourism development and poverty alleviation to connect completely. The tourism development directly bears the function of rural poverty alleviation. All the favorable situations show that the rural tourism industry is rapidly developing, poverty alleviation is being continued to promote, and the farmers' per capita net income directly benefits from the tourism poverty alleviation.

Fifth, ecological environment protection must be taken into account in the development of poverty alleviation in poor villages. In the process of tourism development, the villagers pay attention to protect the ecological environment, which promotes the sustainable development in the rural tourism poverty alleviation.

\section{Conclusions and Recommendations}

As a typical case of success for China's rural poverty alleviation, Chixi village study has universal practical significance. This study extends the successful experience of poverty alleviation about the poor rural areas in 5A grade scenic area in China. But there are many problems for further research, such as, what will happen about impoverished rural village community construction when we implement tourism poverty alleviation in impoverished village? The villagers' income has increased, but do they feel happier? How do the women play their role in the process of tourism poverty alleviation? All these problems are very meaningful, and it is also the focus of follow-up study.

\section{References}

Ashley, C., Roe, D., \& Goodwin, H. (2001). Pro-poor tourism strategies: Making tourism work for the poor. A review of experience. Pro-Poor Tourism Report No. 1, ODI, IIED, CRT.

Baidu Encyclopedia. (n.d.). Retrieved from http://baike.baidu.com/item/\%E8\%B4\%AB\%E5\%9B\%B0/5340280?fr=aladdin

Chen, Q., \& Ji, J. (2016). Study on the path of rural tourism precise poverty alleviation. Journal of Fujian Forum, 412(5), 196-200. 
China News. (2016). A total of 70 million 170 thousand Chinese poor population has 14 contiguous poor land. Retrieved from http://www.chinanews.com/gn/2015/11-03/7603915.shtml

Deng, X., Zeng, L., \& Luo, M. (2015). Study on the accurate identification of tourism poverty alleviation under the background of accurate poverty alleviation. Journal of Ecological Economy, 31(4), 92-98.

Frechtling, D. C. (1974). A model for estimating travel expenditures. Journal of Travel Research, 12(4), 9-12.

Kennedy, K., \& Dornan, D. (2009). An overview: Tourism non-governmental organizations and poverty reduction in developing countries. Asia Pacific Journal of Tourism Research, 14(2), 183-200.

Kiernan, K. (2013). The nature conservation, geotourism and poverty reduction nexus in developing countries: A case study from the Lao PDR. Geoheritage, 5(3), 207-225.

National Administration of People's Republic of China. (2016). Circular on issuing the action plan for rural tourism poverty alleviation projects. No. 121.

Wang, S., \& Guo, Z. (2015). Study on the precision of poverty alleviation in China. Journal of Guizhou Social Sciences, 305(5), 174-150.

Wassenaar, D. J. (1981). California visitor impact model. California Office of Tourism.

Zhang, Z. (2012). Study on mechanism and trend of tourism poverty alleviation -- Also on discussion the enlightenment of the poverty belt around Beijing and Tianjin. Journal of the Ideological Front, 38(2), 104-108. 